\title{
The prevalence and significance of circulating antibodies to gastric intrinsic factor and parietal cells in gastric carcinoma
}

\author{
BERTA UNGAR, R. G. STRICKLAND, AND C. M. FRANCIS \\ From the Clinical Pathology Department, the Royal Melbourne Hospital, and the Clinical Research Unit, \\ Walter and Eliza Hall Institute of Medical Research, Royal Melbourne Hospital, Melbourne, Victoria, \\ Australia
}

SUMMARY The prevalence of circulating antibodies to gastric intrinsic factor and parietal cells was examined in 60 patients with histologically proven gastric carcinoma and was found not to differ from the prevalence of these antibodies in control subjects of similar age and sex distribution.

Amongst the 60 patients with gastric carcinoma seven were thought to have actual or potential pernicious anaemia.

The absence of an increased prevalence of antigastric antibodies in gastric carcinoma indicates that gastritis itself, whether autoimmune or not, is the likely common denominator underlying the predisposition to gastric carcinoma in both pernicious anaemia and chronic atrophic gastritis.

The studies of Kaplan and Rigler (1945) and Mosbech and Videbaek (1950) established that pernicious anaemia is associated with an incidence of gastric carcinoma approximately three times greater than that expected for the population at large.

On the basis of a study of 35 patients with gastric carcinoma Shearman, Finlayson, Wilson, and Samson (1966) suggested that the extent of this association may have been underestimated. We have investigated this possibility by estimating serum vitamin $B_{12}$ levels and the prevalence of circulating antibodies to gastric intrinsic factor and parietal cells in 60 patients with histologically proven gastric carcinoma. The prevalence of antigastric antibodies is compared with that in control subjects of similar age and sex distribution.

\section{Patients and Methods}

The 60 patients with gastric carcinoma comprised 37 men and 23 women. Blood samples were requested from patients with a diagnosis on admission or subsequently of gastric carcinoma admitted to the Royal Melbourne Hospital over a period of three years. Only those in whom a gastric carcinoma was histologically proven at operation or necropsy were included in this series. The age and sex distribution of the patients is shown in Tables I and II.

Received for publication 12 August 1971.
The control subjects for tests for antibody to intrinsic factor were 500 blood donors and 1,100 hospital patients (Ungar, 1968). The control subjects for tests for antibody to parietal cells were 600 blood donors and apparently healthy members of elderly citizens' clubs (Ungar, Stocks, Martin, Whittingham, and Mackay, 1968).

Antibody to intrinsic factor was detected by the coated-charcoal method (Gottlieb, Lau, Wasserman, and Herbert, 1965) as modified by Ungar (1967): it was considered to be present when the titre exceeded $5 \mathrm{ng}$ units per ml serum (Irvine, 1966). Antibody to parietal cells was detected by the double-layer immunofluorescent technique using rat stomach (Whittingham and Mackay, 1969).

Serum vitamin $\mathbf{B}_{12}$ levels were measured by microbiological assay with Euglena gracilis (Anderson, 1964).

\section{Results}

Circulating antibody to gastric intrinsic factor was found in one female patient and circulating antibody to gastric parietal cells was found in seven female and six male patients out of a total number of 23 female and 37 male patients with gastric carcinoma.

The distribution of positive tests for these antibodies according to age and sex in patients with gastric carcinoma and control subjects is shown in Tables I and II. 


\begin{tabular}{lll}
\hline Age $(y r)$ & $\begin{array}{l}\text { No. of Patients with } \\
\text { Factor }\end{array}$ & $\begin{array}{l}\text { Gastibodies to Gastric Intrinsic } \\
\text { Patients }\end{array}$ \\
\cline { 2 - 3 } Controls & $0 / 0$ \\
\hline Females & $0 / 300$ & $0 / 2$ \\
$11-40$ & $1 / 200$ & $1 / 21^{2}$ \\
$41-60$ & $3 / 300^{2}$ & \\
$>60$ & & $0 / 2$ \\
Males & $0 / 300$ & $0 / 8$ \\
$11-40$ & $0 / 200$ & $0 / 27^{2}$ \\
$41-60$ & $1 / 300^{2}$ & 800 \\
$>60$ &
\end{tabular}

Table I Prevalence of antibodies to gastric intrinsic factor in 60 patients with gastric carcinoma and 1,600 controls ${ }^{1}$

${ }^{1}$ The apparent differences in prevalence of antibodies to gastric intrinsic factor between control and carcinoma patients were not statistically significant

'P $>0 \cdot 10$ using Fisher's exact test for $2 \times 2$ contingency tables.

\begin{tabular}{lll}
\hline Age $(y r)$ & \multicolumn{2}{l}{$\begin{array}{l}\text { No. of Patients with Antibodies to Gastric Parietal } \\
\text { Cells }\end{array}$} \\
\cline { 2 - 3 } & Controls & $\begin{array}{l}\text { Gastric Carcinoma } \\
\text { Patients }\end{array}$ \\
\hline Females & $5 / 100$ & $0 / 0$ \\
$15-40$ & $15 / 100$ & $0 / 2$ \\
$41-60$ & $21 / 100^{2}$ & $7 / 21^{2}$ \\
$>60$ & & \\
Males & $2 / 100$ & $0 / 2$ \\
$15-40$ & $4 / 100$ & $0 / 8$ \\
$41-60$ & $18 / 100^{2}$ & $6 / 27^{2}$ \\
$>60$ & & \\
\hline
\end{tabular}

Table II Prevalence of antibodies to gastric parietal cells in 60 patients with gastric carcinoma and 600 control subjects ${ }^{1}$

${ }^{1}$ The apparent differences in prevalence of antibodies to gastric parietal cells between control and carcinoma patients were not statistically significant

'p $>0.10$ using Fisher's exact test for $2 \times 2$ contingency tables.

There were no significant differences in the prevalence of antibodies to intrinsic factor or parietal cells when patients with gastric carcinoma were compared with the control subjects in appropriate age groups. The lack of significant differences in prevalence of these antibodies between carcinoma patients and controls was observed in both sexes.

Reduced serum vitamin $B_{12}$ levels $(<150 \mathrm{pg} / \mathrm{ml})$ were present at the time of diagnosis of gastric carcinoma in five out of 59 patients tested. One patient was not tested and another patient was receiving parenteral vitamin $B_{12}$ therapy for pernicious anaemia diagnosed elsewhere 10 years before the diagnosis of gastric carcinoma was made.

\section{Discussion}

Gastric carcinoma is said to supervene in $12 \%$ of patients with pernicious anaemia (Kaplan and Rigler, 1945). The observations by Shearman et al (1966) in 35 patients with gastric carcinoma revealed a high incidence of pernicious anaemia $(20 \%)$ in gastric carcinoma.

In the present series of 60 cases of gastric carcinoma, the occurrence of pernicious anaemia 10 years before in one patient, the presence of vitamin $\mathbf{B}_{12}$ deficiency suggested by low serum vitamin $\mathbf{B}_{12}$ levels $(150 \mathrm{pg} / \mathrm{ml})$ in five patients at the time of diagnosis of gastric carcinoma, and the presence of antibody to intrinsic factor in another patient supported an increased coincidence of pernicious anaemia and gastric carcinoma, the actual or potential incidence being seven cases of pernicious anaemia in 60 cases of gastric carcinoma (12\%). This estimated incidence is based on the assumption that the remaining patients with gastric carcinoma had no special predisposition to pernicious anaemia as they did not have an increased prevalence of antigastric antibodies when compared with control subjects.

The estimated incidence of pernicious anaemia in gastric carcinoma in the present series is lower than that reported by Shearman et al (1966). These findings, however, confirm those of Kravetz, Van Noorden, and Spiro (1967) and of te Velde (1967) who found no increased prevalence of parietal cell antibody in gastric carcinoma. In addition the present study has demonstrated that the prevalence of intrinsic factor antibody is not increased in gastric carcinoma.

Patients with simple atrophic gastritis have also been shown to have an increased incidence of gastric carcinoma (Walker, Strickland, Ungar, and Mackay, 1971). These patients do not have circulating antigastric antibodies and have no special predisposition to develop pernicious anaemia (Strickland, Ungar, and Mackay, 1970).

Although it remains uncertain what proportion of gastric carcinomas are preceded by atrophic gastritis, the present findings together with those of Walker et al (1971) indicate that it is the gastric lesion itself independent of accompanying autoimmune reactions which underlies the predisposition to gastric carcinoma in both pernicious anaemia and chronic atrophic gastritis.

We wish to thank Dr D. C. Cowling and Dr S. Whittingham for help and guidance; Dr J. M. Mathews for help with statistics; the medical staff of the Royal Melbourne Hospital for access to the medical records of the patients; Dr J. T. Andrews for 
radioisotope services; Mrs P. Krupinska, Mrs B. M. White, and Miss M. J. Pittaway for technical assistance.

R.G.S. is supported by a grant from the National Health and Medical Research Council of Australia.

\section{References}

Anderson, B. B. (1964). Investigations into the Euglena method for the assay of vitamin $B_{12}$ in serum. J. clin. Path., 17, 14-26.

Gottlieb, C., Lau, K. S., Wasserman, L. R., and Herbert, V. (1965). Rapid charcoal assay for intrinsic factor (IF), gastric juice unsaturated $B_{12}$ binding capacity, antibody to IF and serum unsaturated $B_{12}$, binding capacity. Blood, 25, 875-884.

Irvine, W. J. (1966). Immunoassay of gastric intrinsic factor and the titration of antibody to intrinsic factor. Clin. exp. Immunol., 1, 99-118.

Kaplan, H. S., and Rigler, L. G. (1945). Pernicious anaemia and carcinoma of the stomach. Amer. J. med. Sci., 209, 339-348.

Kravetz, R. E., Van Noorden, S., and Spiro, H. M. (1967). Parietal-cell antibodies in patients with duodenal ulcer and gastric cancer. Lancet, 1, 235-237.

Mosbech, J., and Videbaek, A. (1950). Mortality from and risk of gastric carcinoma among patients with pernicious anaemia. Brit. med. J., 2, 390-394.

Shearman, D. J. C., Finlayson, N. D. C., Wilson, R., and Samson, R. R. (1966). Carcinoma of the stomach and early pernicious anaemia. Lancet, 2, 403-405.

Strickland, R. G., Ungar, B., and Mackay, I. R. (1970). Natural history of chronic atrophic gastritis. Aust. Ann. Med., 19, 419.

Te Velde, K. (1967). Parietal Cell Antibodies, Chronic Gastritis and Pernicious Anaemia. Thesis, State University, Groningen, Netherlands.

Ungar, B. (1967). Detection and titration of antibody to intrinsic factor by a modified charcoal method. Aust. J. exp. Biol. med. Sci., 45, 317-321.

Ungar, B. (1968). Antibody to gastric intrinsic factor in blood donors and hospital patients. Aust. Ann. Med., 17, 107-109.

Ungar, B., Stocks, A. E., Martin, F. I. R., Whittingham, S., and Mackay, I. R. (1968). Intrinsic-factor antibody, parietal-cell antibody, and latent pernicious anaemia in diabetes mellitus. Lancet, 2, 415-418.

Walker, I. R., Strickland, R. G., Ungar, B., and Mackay, I. R. (1971). Simple atrophic gastritis and gastric carcinoma. Gut, 12, 906-911.

Whittingham, S., and Mackay, I. R. (1969). Laboratory methods for diagnosis of autoimmune disease. Med. J. Aust., 1, 1200-1205. 